\title{
Evaluation of risk factors for thrombophilia in patients with cerebral venous thrombosis
}

\author{
Serebral venöz tromboz geçiren hastaların trombofilik risk faktörleri \\ açısından değerlendirilmesi
}

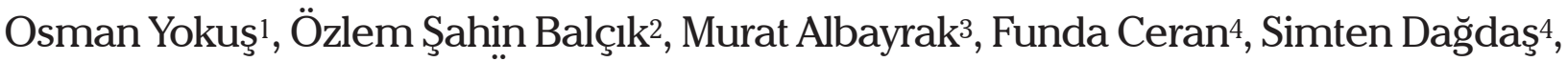 \\ Mesude Yılmaz ${ }^{4}$, Gülsüm Özet ${ }^{4}$ \\ ${ }^{1}$ Department of Hematology, Sema Hospital, Istanbul, Turkey \\ 2 Department of Hematology, Fatih University Medical School, Ankara, Turkey \\ ${ }^{3}$ Department of Hematology, Dışkapı Yıldırım Beyazıt Education and Research Hospital, Ankara, Turkey \\ ${ }^{4}$ Department of Hematology, Numune Education and Research Hospital, Ankara, Turkey
}

\begin{abstract}
Objective: The increased risk for thrombosis is known as hypercoagulability or thrombophilia. In our study, we aimed to determine the frequency of the identified defects for thrombophilia in patients with central venous thrombosis aged under $\mathbf{5 0}$ years and to compare results with the findings in the current literature. Materials and Methods: Forty-three patients (16-50 years old) were retrospectively evaluated. Thrombophilia investigation included determinations of protein $\mathrm{C}$, protein $\mathrm{S}$, antithrombin, and activated protein C resistance, factor V Leiden (FVL), prothrombin 20210A (PT 20210) and methylene tetrahydrofolate reductase (MTHFR) C677T mutations, antiphospholipid antibodies (APA), factor VIII levels, and homocysteine levels.

Results: We detected a single thrombophilic defect in $67.4 \%$, two defects in $27.9 \%$ and three defects in $4.7 \%$ of our patients. The most common thrombophilic defect was mutation in the MTHFR gene (41.8\%), and this was followed by the FVL mutation (34.9\%).

Conclusion: Since the prevalence of individual thrombophilic defects varies in each population, ethnic group and geographical location, screening for thrombophilic defects in patients presenting with cerebral venous thrombosis should primarily investigate the most frequent thrombophilia risk factors. (Turk J Hematol 2010; 27: 162-7)
\end{abstract}

Key words: Cerebral venous thrombosis, thrombophilia, thrombophilic defects

Received: October 4, 2009

Accepted: March 22, 2010

\section{Özet}

Amaç: Tromboz riskinin artması hiperkoagulabilite ya da trombofili olarak bilinmektedir. Çalışmamızda, serebral venöz tromboz gelişen ve trombofilik defekt saptanan 50 yaş ve altı hastalarımızda tespit edilen trombofilik defektleri, sıklığını değerlendirmek ve literatür bilgileriyle karşılaştırmak amaçlanmıştır. 
Yöntem ve Gereçler: 16-50 yaş arasında 43 hasta retrospektif olarak değerlendirildi. Trombofili tetkiki olarak protein $\mathrm{C}$, protein $\mathrm{S}$, antitrombin eksikliği, aktive protein $\mathrm{C}$ rezistansı, faktör $\mathrm{V}$ Leiden (FVL), protrombin 20210A (PT 20210), metilentetrahidrofolat redüktaz (MTHFR) gen mutasyonları, antifosfolipid antikorları (AFA), faktör VIII ve homosistein yüksekliği araştırıldı.

Bulgular: Hastalarımızın \%67.4'ünde tek, \%27.9'unda iki, \%4.7'sinde üç trombofilik defekt saptadık. En sık saptanan defekt MTHFR gen mutasyonu (\%41.8) idi, bunu FVL mutasyonu (\%34.9) takip etti. Sonuç: Trombofili etkenlerinin sıklı̆̆̆, etnik farklılık ve coğrafi bölgelere göre değişebildiğinden, her toplum serebral venöz tromboz kliniği ile başvuran hastalarda öncelikle sık görülen trombofili etkenlerini araștırmalıdır. (Turk J Hematol 2010; 27: 162-7)

Anahtar kelimeler: Serebral venöz tromboz, trombofili, trombofilik defektler

\section{Introduction}

Thrombosis is abnormal clot formation in the vascular system through the interaction of various vascular, cellular and humoral factors. It has been long known that alterations in the vascular wall, blood flow and blood composition (widely known as 'Virchow's triad') cause thrombosis.

The impairment of the delicate balance in the hemostatic process due to the deficiency of natural anticoagulants or defects in the fibrinolytic pathway may result in hypercoagulability [1]. An increased risk for thrombosis is known as hypercoagulability or thrombophilia. Generally, thrombophilia is the general term covering a range of hereditary or acquired conditions [2]. Currently, arterial and venous thrombosis are among the most common causes of morbidity and mortality [3].

In random patient populations, thrombophilic factors leading to a predisposition to thrombosis can be detected in approximately one-third of patients with venous thromboembolism. Hereditary thrombophilia is detected in more than half of the patients in whom thrombophilic defects are present. The risk for thrombosis increases in the presence of multiple thrombophilic defects [3]. Hereditary thrombophilic factors and their frequencies exhibit some variations in different populations or patient groups [4-8]. Ischemic stroke (IS) is usually associated with arterial diseases (e.g. carotid stenosis) or heart diseases (e.g. atrial fibrillation). In studies assessing the role of hereditary thrombophilia in the etiology of cerebral arterial and cerebral venous thrombosis (CAT, CVT), the risk for stroke was found to increase in the presence of different thrombophilic factors [9-16]. Hypercoagulable states are responsible for $5-10 \%$ of all IS cases, and hereditary thrombophilia is especially more common in the etiology of IS in the younger subgroup of patients [17].
In the present study, we aimed to assess the frequency of the identified defects for thrombophilia in patients with CVT and thrombophilic defects aged $\leq 50$ years and to compare our data with the reports in the literature.

\section{Materials and Methods}

\section{Patients}

Forty-three patients (30 females, 13 males; median age: 36 years; range: 16-50) with CVT and thrombophilic defects aged $\leq 50$ years were included in the study. All subjects were diagnosed to have CVT by the neurology clinics, and each patient was consulted with the hematology clinic to explore the etiology of the underlying thrombophilic factor. CVT was diagnosed by means of magnetic resonance imaging (MRI). Chronic liver diseases, diabetes mellitus, dyslipidemia, presence of central venous catheter, history of recent surgical procedures, myeloproliferative diseases, paroxysmal nocturnal hemoglobinuria, malignancies, autoimmune diseases, hormone replacement therapy, and oral contraceptive usage were the exclusion criteria. Laboratory tests were performed under the following conditions: 15 days after discontinuation of heparin or its derivatives, four weeks after discontinuation of coumadin derivatives, and three months later in patients with a history of thrombosis. The tests were repeated in the event of positive results. Oral informed consent were obtained from all patients.

\section{Assessments}

Antithrombin (AT) activity, protein C (PC) activity, total and free protein S (PS) antigen and activity, activated protein $\mathrm{C}$ resistance (APC-R), factor $\mathrm{V}$ Leiden (FVL) G1691A, prothrombin 20210A (PT 20210), and methylene tetrahydrofolate reductase (MTHFR) C677T mutations, factor VIII (FVIII) levels, fasting homocysteine levels, and antiphospholipid 
antibodies (APA) (anticardiolipin antibodies [ACA] IgG and ACA IgM, and lupus anticoagulant [LA]) were assessed in our study. MTHFR C677T mutations were assessed by commercial polymerase chain reaction (PCR) kits (MTHFR LC PCR, QIAGEN). Factor II (prothrombin) G20210A and FVL mutations were determined by commercial kits (Roche Diagnostics). "LightCycler 1.5 Roche" real-time PCR device was used in this study. AT, PC, PS, APC-R, LA, and FVIII levels were assessed in citrated peripheric blood samples drawn after a 12-hour fast, which were centrifuged at $1500 \mathrm{x}$ g for 15 minutes. Citrated samples were stored at $-20^{\circ} \mathrm{C}$ until testing. PC, PS, AT and FVIII were studied using commercial kits (Dade Behring), and APC-R was determined by a Dade Behring proC global kit. These analyses were performed on the BCS instrument (Dade Behring). Homocysteine levels were evaluated using Recipe commercial kits (Recipe Chemical and Instruments $\mathrm{GmbH}$, Munich, Germany) by Shimadzu HPLC analyzer. A laboratory reference range study performed with 40 healthy individuals was established to determine the cut-off value to define PC (70-140\%), PS (58-127\%), AT (75-125\%) and FVIII (70-150\%) activity. LA-sensitive activated partial thromboplastin time (aPTT) reagent PTT-LA (Diagnostica Stago) test was performed for the patients with high levels of aPTT. Presence of heparin, intrinsic pathway factor deficiencies, factor inhibitors, and dysfibrinogenemia was ruled out. In the presence of LA, the plasma clotting time increases. A difference of 8 seconds between the two clotting times is thought to be positive for LA [18,19]. These analyses were performed on the Diagnostica Stago STart ${ }^{\circledR} 4$ Hemostasis Analyzer (Diagnostica Stago, France).

ACA IgM and ACA IgG levels were evaluated by Intec cardiolipin IgM and IgG commercial ELISA kits on a Biomaster instrument. ACA IgM and ACA IgG of less than 2.0 PL-U/ml were accepted as normal range. The determination of $>12 \mathrm{PL}-\mathrm{U} / \mathrm{ml}$ value in at least two separate measurements was considered positive. The normal range of homocysteine in plas$\mathrm{ma} /$ serum was accepted to be between 5.5-14 $\mu \mathrm{mol} / \mathrm{L}$. A minimum of two determinations of homocysteine level $>14 \mu \mathrm{mol} / \mathrm{L}$ was considered as "high".

All blood samples were drawn after formal written consent was obtained from the patients. The study was carried out in accordance with the Helsinki Declaration.

\section{Statistical analysis}

SPSS 11.5 for Windows Statistical Software Package was used to analyze the data. The descriptive statistics used for continuous variables were percentage (\%) and mean \pm standard deviation for categorical variables. Fisher's exact or chi-square test was used for categorical comparisons. Statistical significance was assigned as $\mathrm{p}$ values lower than 0.05 .

\section{Results}

Demographical properties of the patients are shown in Table 1. A previous thrombotic episode was present in 2 patients (4.7\%) and a family history of a thrombotic episode was observed in 3 patients (6.9\%). Among all cases, 38 patients (88\%) were on antithrombotic medication (aspirin, coumadin, and low molecular weight heparin, either as single agents or in combinations). We detected a single thrombophilic defect in 29 (67.4\%), two defects in $12(27.9 \%)$ and three defects in 2 (4.7\%) of our patients. There was no significant difference between male and female patients with regard to the presence of a single or combined thrombophilic defects $(p=0.491)$. The frequencies of the thrombophilic defects that we could detect were as follows: The most frequent thrombophilic defect was a defect in the MTHFR gene, present in $41.8 \%(n=18)$ of the patients; 13 of the patients were heterozygote and 5 were homozygote. This defect was present as a single defect in $50 \%$ and as a joint defect with others in $50 \%$ of our patients. The second most common thrombophilic defect was FVL mutation, which was observed in $34.9 \%(n=15)$ of the patients, with 13 patients being heterozygote and 2 cases homozygote. Other frequent thrombophilic defects were the presence of APA and PS deficiency, which were

Table 1. Demographic characteristics of the patients

\begin{tabular}{lc}
\hline Patients (n) & $\mathbf{4 3}$ \\
\hline Males (n) & $13(30.2 \%)$ \\
Females (n) & $30(69.8 \%)$ \\
Median age (overall) (years) & $36(16-50)$ \\
Median age (females) (years) & $35(16-49)$ \\
Median age (males) (years) & $37(20-50)$ \\
Previous thrombotic events & $2(4.7 \%)$ \\
Family history of thrombotic events & $3(6.9 \%)$ \\
Antithrombotic medication & $38(88 \%)$ \\
\hline
\end{tabular}


observed in $18 \%(n=8)$ of the patients. This was followed by elevated FVIII and homocysteine levels, detected in only 2 patients. Similarly, PC deficiency was also detected in 2 patients. AT deficiency was in the screening program but was not detected in any of our patients. Nine of the patients with a mutation in the MTHFR gene, 6 patients with a FVL mutation and 5 patients with APA had combined thrombophilic defects. The most frequent pair of thrombophilic defects was the combination of a defect in the MTHFR gene + FVL mutation $(n=5)$, followed by a defect in the MTHFR gene + APA $(9 \%, n=4)$. The difference in frequencies between male and female patients was not statistically significant in any of the above-mentioned thrombophilic defects. The frequencies of the various thrombophilic defects are shown in Tables 2 and 3. Recurrent abortus coexisted with CVT in 3 of our patients and in 1 CVT patient, retinal artery thrombosis was also present.

\section{Discussion}

Thromboembolism manifests itself mostly in adults and is a multicausal clinical entity [2]. Increasingly more reports in the literature demonstrate that hereditary defects are as important as acquired factors in the etiology of thromboembolic disease in adults $[5,6,8,20]$. However, several issues are still under investigation, such as in which populations, age groups and in the presence of which acquired factors will hereditary defects cause a tendency towards clinical thrombosis and which combination(s) constitute a strong synergy [21,22]. In a study conducted on patients with venous thromboembolism [23], thrombophilia was found in $41 \%$ of the patients, and in $32 \%$, it involved a genetic cause. The FVL was found in $15 \%$, followed by natural anticoagulant dysfunction (11\%). Similar to our results, the authors observed that thrombophilia frequency did not change significantly with age or gender. Hankey et al. [24] performed a casecontrol study of 219 hospital cases with a first-ever IS and 205 randomly selected community control subjects in order to identify the role of hereditary thrombophilia in IS. They did not observe significant differences in the prevalence of thrombophilia between cases and control subjects or between pathogenic subtypes of IS. In another case-control study reported by Cantu et al. [25], the potential association among homocysteine, folate and vita-
Table 2. Prevalence of hereditary thrombophilic factors and gender distribution

\begin{tabular}{|c|c|c|c|c|c|c|}
\hline & \multicolumn{2}{|c|}{$\begin{array}{c}\text { Males } \\
(n=13)\end{array}$} & \multicolumn{2}{|c|}{$\begin{array}{c}\text { Females } \\
(n=30)\end{array}$} & \multicolumn{2}{|c|}{$\begin{array}{c}\text { Total } \\
(n=43)\end{array}$} \\
\hline & n & $\%$ & $\mathbf{n}$ & $\%$ & $\mathbf{n}$ & $\%$ \\
\hline $\mathrm{PC}$ & 0 & 0 & 2 & 6.7 & 2 & 4.7 \\
\hline PS & 1 & 7.7 & 7 & 23.3 & 8 & 18.6 \\
\hline MTHFR & 6 & 46.2 & 12 & 40 & 18 & 41.8 \\
\hline PT 20210 & 2 & 15.4 & 2 & 6.7 & 4 & 9.3 \\
\hline FVL & 5 & 38.5 & 10 & 33.3 & 15 & 34.9 \\
\hline FVIII & 1 & 7.7 & 1 & 3.3 & 2 & 4.7 \\
\hline APA & 1 & 7.7 & 7 & 23.3 & 8 & 18.6 \\
\hline Homocysteine & 1 & 7.7 & 1 & 3.3 & 2 & 4.7 \\
\hline
\end{tabular}

Elevation

PC: Protein C deficiency; PS: Protein S deficiency; FVL: Factor V Leiden G1691A mutation; MTHFR: 5,10-Methylenetetrahydrofolate reductase C677T mutation; PT 20210: Prothrombin G20210A mutation; FVIII: Elevated factor VIII levels; APA: Antiphospholipid antibody (anticardiolipin antibody IgG, IgM and lupus anticoagulant)

Table 3. The distribution of single and combined mutations in cases of cerebral venous thrombosis

$\begin{array}{ll} & \text { Single thrombophilic defect: } 29(67.4 \%) \\ & \text { Two defects: } 12(27.9 \%) \\ & \text { Three defects: } 2(4.7 \%)\end{array}$

MTHFR: $41.8(n=18 ; 13$ heterozygotes, 5 homozygotes)

Most frequent $\quad$ FVL: $34.9(n=15 ; 13$ heterozygotes, thrombophilic defects (\%) 2 homozygotes)

APA: $18.6(n=8)$

Protein S: $18.6(\mathrm{n}=8)$

PT 20210: 9.3 ( $n=4 ; 4$ heterozygotes)

\begin{tabular}{|c|c|}
\hline \multirow{9}{*}{$\begin{array}{l}\text { Frequency of the } \\
\text { combined mutations (\%) }\end{array}$} & Most frequent: 20.9 MTHFR $(n=9)$ \\
\hline & $\begin{array}{l}2^{\text {nd }} \text { most frequent: } 13.9 \mathrm{FVL}(\mathrm{n}=6) \\
\text { and } 11.6 \mathrm{APA}(\mathrm{n}=5)\end{array}$ \\
\hline & MTHFR+FVL: $6.9(\mathrm{n}=3)$ \\
\hline & MTHFR+APA: $6.9(n=3)$ \\
\hline & MTHFR+PS, MTHFR+FVL+PS, \\
\hline & MTHFR+FVL+PT 20210, FVL+PS, \\
\hline & PS+PT 20210, FVIII+APA, \\
\hline & APA+Homocysteine Elevation: \\
\hline & $2.3(n=1)$ \\
\hline
\end{tabular}

PC: Protein C deficiency; PS: Protein S deficiency; FVL: Factor V Leiden G1691A mutation; MTHFR: 5,10-Methylenetetrahydrofolate reductase C677T mutation; PT 20210: Prothrombin G20210A mutation; FVIII: Elevated factor VIII levels; APA: Antiphospholipid antibody (anticardiolipin antibody IgG, IgM and lupus anticoagulant)

min B12 levels and the common C677T mutation in the MTHFR gene was examined in patients with CVT. The authors also performed thrombophilic tests and reported a higher prevalence of APC-R 
and presence of FVL and mutation in the PT gene (G20210A) in CVT patients [25]. In another study conducted in patients with CVT [26], infections and postpartum state were found to be the most common predisposing factors for CVT, and the prevalence of genetic thrombophilia was 5\%. In our study, CVT did not develop during the gestation or puerperal period in female cases. In populations with low folate levels and low socioeconomic status, mutation in the MTHFR gene and hyperhomocysteinemia increase the risk for IS $[9,10,15,25]$. In a study performed on 125 patients by Nadir et al. [27], there was no correlation between high plasma homocysteine levels and C677T mutation in the MTHFR gene. In our study, only two cases among 43 were determined to have homocysteine levels above the normal $(14 \mu \mathrm{mol} / \mathrm{L})$. No MTHFR gene mutation was detected in these cases. The fasting homocysteine levels of the remaining 41 cases were within the normal range.

In the present study, we detected two or more thrombophilic defects in $32 \%$ of our patients. This finding shows that approximately one-third of all patients presented with combined thrombophilic defects. Thus, the search for these defects should not be stopped when one defect is detected; rather it would be an appropriate approach to continue the scan for at least 3-5 of the most common thrombophilic defects. The presence of MTHFR and FVL mutations and APA in our patients with CVT was in accordance with a study performed on pregnant women with venous thromboembolism [28].

Similar to our results, in a study performed in Australia [29], the MTHFR C677T polymorphism was the most common inherited thrombophilic defect. In that study, the birth prevalences of heterozygosity and homozygosity for the MTHFR C677T polymorphism were $37.3 \%$ and $12.4 \%$, respectively. The authors concluded that inherited thrombophilic polymorphisms are common in the Caucasian Australian population, but the reason why thromboembolic disorders are not observed in most of these subjects may be the absence of additional risk factors, which facilitate the clinical manifestation of thromboembolism [29]. The association between the MTHFR C677T polymorphism and vascular disease is still a matter of debate $[9,10,15,16,30]$. The high number of polymorphic alleles and the differential distribution of these polymorphisms among various ethnic groups (more prevalent among subjects of Caucasian decent than blacks) are some of the factors that make it difficult to comment on the results of various studies and to derive general conclusions [16].

In conclusion, since the prevalence of individual thrombophilic defects varies in different ethnic groups and geographical locations, in each population, screening for thrombophilic defects in patients presenting with CVT should primarily involve the most frequent thrombophilia risk factors. Such an approach will enable the initiation of prophylactic and therapeutic measures in the appropriate cases and thus decrease the economic burden for healthcare. Further studies involving larger patient populations are mandatory for the evaluation of the relevance of our results with current clinical practice.

\section{Conflict of interest}

No author of this paper has a conflict of interest, including specific financial interests, relationships, and/or affiliations relevant to the subject matter or materials included in this manuscript.

\section{References}

1. Esmon CT. Protein C. The regulation of natural anticoagulant pathways. Science 1987;235:1348-52.

2. Rosendaal FR. Venous thrombosis, a multicausal disease. Lancet 1999;353:1167-73.

3. Friedman KD, Rodgers GM. Thrombosis and antithrombotic therapy. In: Greer JP, Foerster J, Lukens J, Rodgers G, Paraskevas F, Glader B, editors. Wintrobe's Clinical Hematology. 11th ed. USA: Lippincott Williams \& Wilkins, 2004: 1713-28.

4. Majluf-Cruz A, Moreno-Hernandez M, Ruiz-de-ChavezOchoa A, Monroy-Garcia R, Majluf-Cruz K, GuardadoMendoza R, Molina-Avila I, Isordia-Salas I, Corona-de la Peña N, Vargas-Vorackova F, Vela-Ojeda J, GarcíaChávez J. Activated protein $\mathrm{C}$ resistance and factor $\mathrm{V}$ Leiden in Mexico. Clin Appl Thromb Hemost 2008;14:428-37.

5. Okumus G, Kiyan E, Arseven O, Tabak L, Diz-Kucukkaya $\mathrm{R}$, Unlucerci $\mathrm{Y}$, Abaci $\mathrm{N}$, Unaltuna $\mathrm{NE}$, Issever $\mathrm{H}$. Hereditary thrombophilic risk factors and venous thromboembolism in Istanbul, Turkey: the role in different clinical manifestations of venous thromboembolism. Clin Appl Thromb Hemost 2008;14:168-73.

6. Kovac M, Mikovic D, Antonijevic N, Rakicevic L, Djordjevic V, Radojkovic D, Elezovic I. FV Leiden mutationandrisk of recurrentvenous thromboembolism in Serbian population. J Thromb Thrombolysis 2008;25:284-7.

7. Kabukcu S, Keskin N, Keskin A, Atalay E. The frequency of factor $\mathrm{V}$ Leiden and concomitance of factor $\mathrm{V}$ Leiden with prothrombin G20210A mutation and methylene 
tetrahydrofolate reductase $\mathrm{C} 677 \mathrm{~T}$ gene mutation in healthy population of Denizli, Aegean region of Turkey. Clin Appl Thromb Hemost 2007;13:166-71.

8. Shen MC, Lin JS, Tsay W. High prevalence of antithrombin III, protein $\mathrm{C}$ and protein $\mathrm{S}$ deficiency, but no factor $\mathrm{V}$ Leiden mutation in venous thrombophilic Chinese patients in Taiwan. Thromb Res 1997;87:377-85.

9. Kawamoto R, Kohara K, Oka Y, Tomita H, Tabara Y, Miki T. An association of 5,10-methylenetetrahydrofolate reductase (MTHFR) gene polymorphism and ischemic stroke. J Stroke Cerebrovasc Dis 2005;14:67-74.

10. Sazci A, Ergul E, Tuncer N, Akpinar G, Kara I. Methylenetetrahydrofolate reductase gene polymorphisms are associated with ischemic and hemorrhagic stroke: dual effect of MTHFR polymorphisms C677T and A1298C. Brain Res Bull 2006;71:45-50.

11. Glueck CJ, Munjal J, Aregawi D, Agloria M, Winiarska M, Khalil Q, Wang P. Thrombophilia-hypofibrinolysis and atherothrombotic cardiovascular disease $<$ or $=$ age 45 years. Transl Res 2007;150:93-100.

12. Tänäsescu R, Ticmeanu M, Nicolau A, Uscätescu V, Cojocaru M, Grecu V, Serbänescu A. Anticardiolipin antibodies, recurrent stroke and vascular events: a prospective study on 210 patients. Rom J Intern Med 2005;43:79-88.

13. Carod-Artal FJ, Nunes SV, Portugal D, Silva TV, Vargas AP. Ischemic stroke subtypes and thrombophilia in young and elderly Brazilian stroke patients admitted to a rehabilitation hospital. Stroke 2005;36:2012-4.

14. Aznar J, Mira Y, Vayä A, Corella D, Ferrando F, Villa P, Estelles A. Factor V Leiden and prothrombin G20210A mutations in young adults with cryptogenic ischemic stroke. Thromb Haemost 2004;91:1031-4.

15. Madonna P, de Stefano V, Coppola A, Cirillo F, Cerbone AM, Orefice G, Di Minno G. Hyperhomocysteinemia and other inherited prothrombotic conditions in young adults with a history of ischemic stroke. Stroke 2002;33:51-6.

16. Voetsch B, Damasceno BP, Camargo EC, Massaro A, Bacheschi LA, Scaff M, Annichino-Bizzacchi JM, Arruda VR. Inherited thrombophilia as a risk factor for the development of ischemic stroke in young adults. Thromb Haemost 2000;83:229-33.

17. Levine SR. Hypercoagulable states and stroke: a selective review. CNS Spectr 2005;10:567-78.

18. Triplett DA. Assays for detection of antiphospholipid antibodies. Thromb Haemost 1994;3:281-7.
19. Triplett DA, Barna LK, Unger GA. A hexagonal(II) phase phospholipid neutralization assay for lupus anticoagulant identification. Lupus 1993;70:787-93.

20. Bombeli T, Basic A, Fehr J. Prevalence of hereditary thrombophilia in patients with thrombosis in different venous systems. Am J Hematol 2002;70:126-32.

21. Lane DA, Mannucci PM, Bauer KA, Bertina RM, Bochkov NP, Boulyjenkov V, Chandy M, Dahlbäck B, Ginter EK, Miletich JP, Rosendaal FR, Seligsohn U. Inherited thrombophilia: part 1. Thromb Haemost 1996;76:651-62.

22. Lawson SE, Butler D, Enayat MS, Williams MD. Congenital thrombophilia and thrombosis: a study in a single centre: Arch Dis Child 1999;81:176-8.

23. Paschóa AF, Guillaumon AT. Impact of screening on thrombophilia for patients with venous thrombosis. Int Angiol 2006;25:52-9.

24. Hankey GJ, Eikelboom JW, van Bockxmeer FM, Lofthouse E, Staples N, Baker RI. Inherited thrombophilia in ischemic stroke and its pathogenic subtypes. Stroke 2001;32:1793-9.

25. Cantu C, Alonso E, Jara A, Martínez L, Ríos C, Fernández Mde L, Garcia I, Barinagarrementeria F. Hyperhomocysteinemia, low folate and vitamin B12 concentrations, and methylene tetrahydrofolate reductase mutation in cerebral venous thrombosis. Stroke 2004;35:1790-4.

26. Khealani BA, Wasay M, Saadah M, Sultana E, Mustafa S, Shohab Khan F, Kamal AK. Cerebral venous thrombosis. A descriptive multicenter study of patients in Pakistan and Middle East. Stroke 2008;39:2707-11.

27. Nadir Y, Hoffman R, Brenner B. Association of homocysteine, vitamin B12, folic acid, and MTHFR C677T in patients with a thrombotic event or recurrent fetal loss. Ann Hematol 2007;86:35-40.

28. Ogunyemi D, Cuellar F, Ku W, Arkel Y. Association between inherited thrombophilias, antiphospholipid antibodies, and lipoprotein A levels and venous thromboembolism in pregnancy. Am J Perinatol 2003;20:17-24.

29. Gibson CS, MacLennan AH, Rudzki Z, Hague WM, Haan EA, Sharpe P, Priest K, Chan A, Dekker GA; South Australian Cerebral Palsy Research Group. The prevalence of inherited thrombophilias in a Caucasian Australian population. Pathology 2005;37:160-3.

30. Yeh PS, Lin HJ, Li YH, Lin KC, Cheng TJ, Chang CY, Ke DS. Prognosis of young ischemic stroke in Taiwan: impact of prothrombotic genetic polymorphisms. Thromb Haemost 2004;92:583-9. 